\title{
Editorial: People Power
}

We would be very far from doubting the sincerity of the majority of our politicians or their integrity. People, in Britain at least, who actually meet politicians from all parties are often pleasantly surprised. They usually find ordinary and sometimes quite able people trying to do their best in difficult circumstances, rather than the monsters of sleaze, hypocrisy and self-centredness of the caricatures. $\mathrm{N}$ or is it the place of $\mathrm{P}$ hilosophy to criticize the policies of governments, particularly not those of democratic governments, popular in themselves and with popular mandates.

W hat, though, does seem a disturbing contemporary trend is for political leaders to present themselves as articulating the feelings of a whole people, particularly when this is over specific issues or events. Should a whole people have just one feeling? W hat happens to those within the society who do not share the feeling? Are they still part of the 'people'? D o they have to hide and go underground? A nd should politics be driven by feeling, however sincere, however worthy, rather than by reason and dispassionate analysis? Whatever is the case with politics, philosophy involves reason and dispassionate analysis. It is at this point that the philosopher may find him or herself at odds with popular feeling, particularly with feelings of the synthetic sort political spinners are tempted to whip up. It is then that the philosopher may find him or herself a stranger in his or her own land, perhaps not for the first time this century. 